\title{
¿Khitipxtansa? Kik vagyunk? Helybeliségen alapuló identitás, etnikai identitás és osztálytudat az ajmaráknál (Xavier Albó)
}

\author{
PesovÁr ZsófiA FordítÁsA
}

Az Altiplanón, Cochabamba megyében élő kecsua paraszti népesség rendkívül mozgékony, talpraesett és fogékony a nem paraszti foglalkozások iránt, kulturális és társadalmi mobilitása nagy, a falu-város kapcsolatok élénkek és konfliktusmentesek. A társadalmi mozgalmaknak nagy hagyományai vannak ezen a vidéken, hiszen Cochabamba volt a bölcsôje annak a paraszti szindikalista mozgalomnak, amely kikényszeríttette az 1953-as agrárreformot.

Ezzel szemben az ajmarákat bemutató antropológiai, szépirodalmi vagy más írások hagyományosan megközelíthetetlen és megérthetetlen rejtélyként, kulturális ôskövületként tárgyalják az ôshonosok e másik csoportját. Én más ajmarákat ismertem meg. Szívósságuk és a saját kultúra és életforma iránti makacs ragaszkodásuk még nagyobbnak is túnt, mint amekkora a Cochabamba megyei kecsuákat jellemzi, noha objektív körülményeik a múltban inkább a beolvadásnak, az asszimilációnak kedveztek. Az ajmarák két szuverén állam, Bolívia és Peru között oszlanak meg, Bolíviában ok alkotják a népesség egyik legjelentôsebb csoportját. Az ország fóvárosa, La Paz közelében élnek - egyébként ez az egyetlen olyan latin-amerikai fôváros, melynek elnevezése ôshonos nyelven (Chukiyaw Marka) ma is általánosan használatos.

Több mint öt esztendôt töltöttem az ajmarák körében. Ez a munka ezeknek az éveknek summája, és elsôsorban arra szolgál, hogy a nyilvánosság elốtt tegyem föl azokat a kérdéseimet, amelyek minden 
megfigyelésem mélyén ott lappangtak. Milyen hovatartozást vallanak magukénak napjaink ajmarái? Mely társadalmi csoporttal azonosítják magukat? Pontosan kikre vonatkozik a jiwasaw jakinakax (mi, emberek) kifejezés? A választ részben belülrôl, részben pedig a társadalmi osztályok nyugati és „tudományos” koncepciójának fölhasználásával fogom megadni, mert az ajmarák nem elszigetelten élnek, hanem a bolíviai társadalomba beágyazottan, ez pedig része a világ gazdasági és szociálpolitikai struktúráinak. Milyen képet alkotnak tehát az ajmarák saját magukról, és hogyan illeszkedik ez a kép a bolíviai társadalom osztályviszonyairól kialakult képbe?

\section{Az ajmara világ gazdasági alapja}

Az Altiplanón élô ajmarák többsége elsôsorban önellátásra termelő mezôgazdasági tevékenységból élô földmúves, termékeik csekély feleslegét értékesítik csak a piacon. Gazdálkodásukat Gutelman nyomán „parcellákon alapuló gazdálkodásnak” nevezhetjük, amely a szigorú önellátás és bezárkózás, valamint a mostoha természeti környezet hatására némileg módosult (Gutelman 1975). A legfontosabb sajátság, hogy minden család több, különbözố magassági-éghajlati zónába esố parcellát is múvel egyidejúleg, részben a falu határában, részben azon kívül. Földmúveléssel, állattenyésztéssel, illetve a holtszezonban kézmúiparral és üzleteléssel foglalkoznak, munkát vállalnak a városban, hogy a szélesebb portfolió segítségével bebiztosítsák magukat az idójárás csapásai ellen. Több mint egymillió ajmara él ilyen körülmények között Bolíviában és több százezer Peruban (ide sorolva az uradalmi cselédek leszármazottait is, és azokat is, akik mindig is ósi közösségeikben éltek).

A földmúves ajmarák között is érdemes néhány alapvetô kategóriát megkülönböztetni. A Titicaca-tavat szegélyezô termékeny földeken éloók megốrizték a parcellarendszert, a föld azonban már nem elegendô a számukra, egy-egy családnak csak néhány barázda jut. 
Emiatt errefelé inkább a kereskedelem indult fejlódésnek, nem pedig a mezógazdaság. Vannak olyan helyek, ahonnan számos ajmara ment el vidéki tanítónak, mások pedig egyszerủen elvándoroltak. Ugyanakkor a Yungasban vagy egyes kedvezó éghajlatú völgyekben élô parasztok értékesebb termékeikkel (gyümölcs, kávé, kokalevél stb.) sikeres szereplôkké váltak a helyi és a távolabbi piacokon egyaránt. Ebben a körben megfigyelhetố a felhalmozási és beruházási folyamatok beindulása, és föllelhetố a vállalkozói mentalitás néhány szembetúnó jegye.

Az ajmarák egy egészen más csoportját alkotják a városi bevándorlók. Ez a csoport még népesebb, mint a földmúveseké, de a számukat nagyon nehéz megbecsülni. Már nem vallják magukat parasztnak, és a környezetük megítélése szerint sem parasztok. Nagy részük La Pazban és Oruróban él, kiskereskedôk, kisiparosok, bányászok, kishivatalnokok, csendôrök, közlekedési biztosok, kontárkômúvesek stb. Gyári munkás és alkalmazott alig van közöttük, ezeket a biztosabb állásokat a valódi városiak töltik be, illetve olyanok, akik már évek óta a városban élnek, és asszimilálódtak. Növekszik ezzel szemben a városba tanulni érkezô középiskolás, esti iskolás, egyetemista ajmarák száma, egy diplomás azonban már nem feltétlenül vallja magát ajmarának.

\section{Ide- vagy odavalósiak vagyunk}

Az ajmarák nagy többsége, fóként a vidékiek számára a legkézenfekvôbb és leginkább sajátjuknak érzett hovatartozás a helybeliség alapján fogalmazódik meg. Elsôsorban nem parasztként vagy ajmaraként, hanem valamely település, tájegység, esetleg tartomány tagjaként tartják számon magukat. Ez természetesen távolról sem jelenti azt, hogy ne lennének helyi, családi, szomszédsági ellentétek, viszályok; ezek azonban nem törlik el az azok között meglévố mély szolidaritást, akik egy helyen születtek, és együtt nốttek fel. A hely- 
beliségnek ez a kitüntetett szerepe okozza az ajmara identitás kétarcúságát: ez az identitás egyszerre szolidáris és frakciózó. [...] A csoportszolidaritásból következóen egy ajmara alig tesz különbséget városi és városi között: mindegyik kívülálló, még akkor is, ha az illetố városi éppen falusi szövetkezetet, szakszervezetet vagy biztosítóegyletet próbálna szervezni.

Ugyanakkor a helybeli identitás mindig valamely másik ajmara csoport ellentéteként fogalmazódik meg: a laymiak például azért laymiak, hogy ezzel kifejezzék, hogy ok nem hukumaniak, akiket a maguk ellentéteként értelmeznek. A macsakaiak ellentétei a guakik és a tiwanakuk és így tovább. Ez az ellentét megfogalmazódik egyegy falu két vége (alvég és felvég), két járás vagy két tartomány között is. Az ellentétek okai látszólag sokfélék (néhány vitás barázda a határon, kié a patakvíz stb.), de még ha ideológiai vagy politikai köntösben jelentkeznek is, mindig kitapintható mögöttük a helybeliségen, helyi születésen alapuló identitás mint fố ok.

A szolidaritásnak és az ellentétnek ez a kettôs játéka valószínúleg az andokbeliség legáltalánosabb vonása. Az egész társadalmi berendezkedés és a hagyományos kultúra mentális struktúrái ennek a gondolatnak az alapján épülnek föl, annyira, hogy számukra a világegyetem is egymással harcoló ellentétek egységét jelenti. Feltételezhetjük, hogy az Inka Birodalom - Tawantinszuju - is az egymással szembenálló csoportok, a négy szuju vagy tartomány egységeként határozódott meg.

\section{Ajmara Indiánok vagyunk}

Leszúkíthetjük-e az önmeghatározást egy földrajzi hely referenciájára? Mit jelent számukra az, hogy egy bizonyos terület lakói ugyanazt a nyelvet beszélik, hasonlók a szokásaik és hasonló életmódot folytatnak, illetve hogy a kívülállók ajmaraként vagy indiánként tartják számon ôket? Az érdekel bennünket, hogyan határozzák meg 
magukat, milyen az önmagukról alkotott képük, a szubjektív perspektívájuk és az óket csoportként megvédó ideológiájuk.

Különbözó szinten ugyan, de minden ajmara tisztában van azzal, hogy másokkal is megosztja ajmara identitását (kulturális identitás), indián voltát (etnikai, pszeudofaji hovatartozás) és - a városi ajmaráktól eltekintve - földmúves identitását (társadalmi-gazdasági identitás; etnikaifaji kicsengése miatt a paraszt voltaképpen az indián egyik szinonimája). [...] És ha az ajmara világ szükségszerúen tele van is ellentétekkel, az ajmarák és a „mások” közötti konfliktusok sokkal gyakoribbak és élesebbek. Mindezek kifejezésére az ajmarák ma is használják saját genealogikus, a többiektôl elkülönítô kifejezésüket: hakinak (szó szerint: ember) nevezik magukat, ami az ajmara, az indián és jellemzốen a földmúves hármas feltételét foglalja magában. Ezzel szemben mindenki mást, aki nem ajmara, és nem is indián vagy földmúves, karának (kara - „meztelen ember”, fehér) vagy misztinek (a „mesztic” ajmarásított alakja) neveznek. Az ajmarák többsége nem tartja fontosnak, hogy megkülönböztesse magát a kecsuáktól; Cochabambában például olyan vidéken, ahol ajmarák és kecsuák egyaránt élnek, ajmara is és kecsua is lehet haki.

\section{Indiánok vagyunk}

Amióta az indián terminust a spanyolok egy egyszerú földrajzi tévedés folytán kitalálták, e közös névvel illették az Újvilág valamennyi bennszülöttjét, akik pedig oly sokféle etnikumhoz tartoztak. [...] A hódítás és a gyarmati kor folyamán az indián szó a faji és etnokulturális jelentéstartalom mellett egyre nyilvánvalóbb társadalmi jelentéstartalmat is magába szívott. A spanyolok, majd a köztársaságiak számára az indián egy alávetett és alávaló csoporthoz tartozó egyént jelölt. Ezt a csoportot a felfedezés idején talált lakosságtól való vérségi leszármazás alapján határozták meg. Ugyanakkor viszont, mihelyt kiemelkedett valaki ebbôl a közegbôl, ôshonos származása 
ellenére is elveszítette az indián elnevezést - ha ô maga talán még nem is, leszármazottai biztosan. A tényleges identitás ezért egyfajta vegyüléke a valós leszármazási elven, a társadalmi - gazdasági alapokon és a szubjektív etnorasszista alapokon álló meghatározásnak. Ez régóta lehetốvé teszi az indián szó szélsôséges manipulációját: idốtlen idốk óta indiánként tartották számon a legalsó társadalmi csoporthoz tartozókat. A szó használata viszonylagos: a társadalmi hierarchia magaslataiból letekintve a lentebb elhelyezkedôk mind indiánok, még akkor is, ha ok nem nevezik magukat annak, és a még alantabb elhelyezkedôk sem nevezik óket indiánnak. [...]

Az ajmarák tudják, hogy az indio elnevezés és identitás számos hátránnyal jár. Indiánnak lenni olyan társadalmi megbélyegzés, melyet nagyon nehéz lemosni, és mindenképpen orvosolni kell. [...] A fogalomnak azonban számos történelmi pillanatban nagy kohéziós ereje volt, számos függetlenségi mozgalom, szabadságharc szervezôdött e generatív kategória alapján. [...] Ha az indiánt faji értelemben értjük, egyértelmú a rasszista konnotáció és elôítélet. Rengeteg legenda és babona kapcsolódik hozzá: szellemi és kulturális alsóbbrendúség, piszok, rossz szag, fertôzés... Annyira, hogy egy ajmara mozgalmár megvallotta nekem: nem akar többé nyilvánosan kezet rázni a miniszterrel, mert legutóbb észrevette, hogy a miniszter az indián delegációval való parolázás után alkohollal fertôtlenítette a kezét...

A rasszista előítéletek jelentôs részét az ajmarák is osztják. Sok indián ismételgeti, hogy ok valóban alsóbbrendú lények, és csak „mások” adhatják meg számukra mindazt, amire a fejlódésükhöz szükségük van. [...]

Ez a kétoldali rasszizmus azonban nem jelenti azt, hogy ne lennének széles körú kapcsolatok a két csoport között: kölcsönös függôségi láncok múködnek, át lehet menni az egyik csoportból a másikba, sốt, még a vegyes házasság sem kizárt, persze, csak fehér férfi és indián nố között. Sokkal inkább egy paternalista, mintsem versengó rasszizmusról van tehát szó (Van den Berghe 1967). Csak az elitnek 
ama új része esetében, amely büszkén vállalja „indián” identitását (továbbra is faji értelemben, megkülönböztetésül a karáktól, azaz a fehérektốl), találhatjuk meg a black powerrel rokonítható versengô szellemet. Az o indiánságuk azonban gyakran nem az átélt valósághoz kapcsolódik, csak szöveg, és szöveg is marad.

\section{Földmúvesek vagyunk}

A Movimiento Nacionalista Revolucionario (Forradalmi Nemzeti Mozgalom) és az agrárreform kizárólag a földmüves szót népszerûsítette az indián vagy ôshonos helyett. Ugyanakkor terjedt el a rosca, amely - mint az oligarchia szinonimája - a tulajdonosokat és birtokosokat jelentette. Ez utóbbi terminus azonnali és átütố sikert aratott. Vidéken a falusiak ma is gyakran úgy emlegetik az agrárreform elốtti idốket, hogy „a rosca korában”. A „,öldmúves” kifejezéstốl azt várták, hogy végleg megszabadítja az indiánokat a megbélyegzéstôl, kifejezi, hogy ezentúl sem a közvélemény, sem az állami intézmények nem alkalmaznak velük szemben diszkriminációt. A kifejezés nyíltan osztályjellegú, ami azt is jelenti, hogy fölülemelkedik a területi, kulturális és nyelvi különbségeken. Az ajmara parasztok talán ekkor érezhették elôször úgy, hogy lehet valami közös bennük és a cochabambaiakban vagy a tarijaiakban.

$\mathrm{Az}$ új kifejezés bevezetése végül is nem alakította át a helyzetet. Az emberek - fent ugyanúgy, mint lent - csakhamar rájöttek, hogy a „földmúves” csak egy új szó az ,indián” helyett, így azután többékevésbé burkolt formában, de tovább élt a korábbi kettôs rasszizmus. [...] Azok pedig, akik akkorra már éppen kezdték fölismerni és új tartalommal megtölteni indiánságuk értékeit, azok azért utasították el a „földmúves” kifejezést, mert jobbára ốk maguk sem voltak már földmúvesek. 


\section{Ajmarák vagyunk}

Az „ajmara” szó által leírt és belülrôl szemlélt világ egyszerre felel meg fajnak, kultúrának és nyelvi csoportnak. Az „ajmara” szó eredetileg kétségtelenül a nyelvre vonatkozott, megkülönböztetendố az ajmara nyelvet a karák spanyoljától, valamint - kivételes alkalmakkor - például a kecsuától vagy más „indián” nyelvektôl. Az ajmarák tulajdonképpen kizárólag ezt a nyelvi sajátságot tekintik ajmara sajátságnak. Az értelmezés, hogy az ajmara nyelven beszéloók kultúrájának egésze, annak sajátságai jelentenék az ajmara kultúrát, inkább kívülrôl származik, a fehérektôl.

A különbözô, ajmarák lakta vidékek lakossága akkor kezdett ráébredni azonosságára, és akkor alakult ki egyfajta pánajmara gondolat, amikor az agrárreformot követóen megindult gyarapodás éveiben, a rádiózás elterjedésével egyre gyakrabban hallhattak ajmara szót a rádióból. 1976-ban már minden állami adónak volt ajmara nyelvú músora, napjainkban pedig a huszonkét La Paz-i adóból hat ajmara nyelven sugároz. [...]

Fontos volt a számtalan kis új egyház szerepe, amelyek jobbára külföldi hittérítôikkel jelentek meg az ajmara területeken. Ezek a protestáns misszionáriusok hajlandóak voltak megtanulni ajmarául, és olyan sok hívet hódítottak el a katolikus egyháztól, hogy válaszként az is hasonló ajmarásításra kényszerült, fớként a II. vatikáni zsinat után. A Biblia és más vallásos tárgyú könyvek ajmara kiadása nagyban segítette az ajmara írásbeliség kialakulását és fejlódését. Paradox módon az egyházak tevékenysége és a külföldi hittérítók segítették elô egy egységes ajmara nyelv és identitás létrejöttét. [...]

Lehetséges, hogy napjainkban a kívülállók pontosabban meg tudják határozni, ki is számít ajmarának, mint maguk az ajmarák, akik nemrégiben még egyáltalán nem használták ezt a kifejezést magukra, és a többi ajmara csoportot csak duális ellentéteik tükrén át láthatták. Talán ez is hozzájárul ahhoz, hogy napjainkban egyre többen használják újra az „indiánt”. 


\section{Na és a csóló?}

A társadalmi identifikációs sémák akkor múködnek nagyszerúen, ha sikerül két tökéletesen ellentétes pontot találnunk: fehér és indián, spanyol és ajmara, vidéki és városi, elnyomott és elnyomó. Sajnos, a valóság soha nem volt ennyire világos és áttekinthetô. Már a gyarmati uralom kezdetétôl létezett egy meszticnek vagy csólónak nevezett, közbensô, harmadik csoport.

Az agrárreformig viszonylag egyszerú volt a helyzet, mivel a csólók nem alkottak külön csoportot az indiánokon belül, nem létezett „csóló rend”, csak csólók voltak, akik egyénileg, nem pedig csoportosan szakadtak ki, pontosabban emelkedtek föl az indián létból. A csólók közvetítő közeget alkottak, és egy sor olyan gazdasági kedvezményben részesültek, amilyenben az indiánok nem. Természetes, hogy ok már a legkevésbé sem tartották magukat indiánnak, sốt, gyakran ôk voltak a leghangosabb indiángyúlölók. [...]

Manapság a helyzet bonyolultabb. Vidéken is egyre általánosabbá és természetesebbé vált a tanulás, a földmúvesek beiratkozhatnak középiskolába, fôiskolára, sôt egyetemre is, de a régi idôktôl eltérốen nem feltétlenül kell kivetkôzniük indián voltukból, nem kell csólóvá válniuk (bár ez még ma is általános dolog). Az indián értelmiségi és városlakó megjelenésével egyre ellentmondásosabb az „indiánok”, az „ajmarák” vagy a „földmúvesek” társadalmi-gazdasági osztályként való azonosítása. 


\section{Mit gondolnak magukról \\ az ajmarák különbözố csoportjai?}

\section{A szubsztantív gazdálkodást folytató altiplanói ajmarák}

Az ajmaráknak még ma is ez a legnépesebb csoportja. A csoportazonosság legfontosabb tényezôi számukra a következók:

A saját csoport földrajzi elhelyezkedése más csoportok földrajzi elhelyezkedésével szemben.

Saját, indián vagy földmúvelô, haki helyzete mint társadalmi és etnikai kategória, szemben a városlakók (az urak, azaz a caballerok vagy wiraquchák) vagyis a karák, misztik vagy vecinok helyzetével.

Vidéki identitása (paraszt, campo haki vagy pampa haki) a kis- és nagyvárosok lakóinak identitásával szemben. [...]

\section{A piacra termeló ajmarák}

Itt fôleg a Yungasban éló ajmarákról van szó, és azokról, akik azokon a földeken telepedtek le, amelyeket a gyarmatosítás idôszakában népesítettek be, továbbá néhány Inquisivi és Loayza megyei völgy lakóiról. Ok elsôsorban eladásra termelnek, és általában monokultúrás termelôkké (pl. kávé, kakaó) váltak. Így nem csupán „földmúvesek” abban az értelemben, hogy „ajmarák” és „indiánok”, hanem az is összeköti ôket, hogy mit visznek a piacra („kávétermelók”, „kakaótermelôk”), ilyenformán ezek is etnikai kategóriák lesznek. [...] Ugyanakkor az etnikai, faji vonások sem túnnek el. Az ajmara származású földmúvesek és piacozók megkülönböztetik magukat a városiaktól (a fehérektól) és a yungasi néger falvak lakóitól, mivel ók, a többiekkel ellentétben ajmarául beszélnek. 


\section{A bányász ajmarák}

A bolíviai bányászok, jóllehet kisebbséget alkotnak az ajmarákon belül, politikai és gazdasági szerepük miatt mégis szót érdemelnek. A kérdés egyrészt az, milyen identitást vallanak magukénak, másrészt pedig az, hogyan viszonyulnak azokhoz az ajmarákhoz, akik nem bányászok. Az ajmara „fơállásban” általában ajmara, nem pedig bányász. Ez azt jelenti, hogy paraszti foglalkozása mellett csak átmenetileg, pénzkereset céljáb ól szegôdik el a bányához, jellemzóen azért, hogy egy rendkívül költséges ünnep vagy egy esküvố kiadásait fedezni tudja. Ilyen alkalmi munkásokat - makipuraszokat - fôleg a kis magánbányákban foglalkoztatnak, ahol egyébként sincsenek szakmunkások, de olykor a nagyobb bányákban is fölvesznek ajmarákat hosszabb-rövidebb idôre. Elsôsorban felszíni munkákat végeznek: útkarbantartási munkálatoknál és építkezéseknél alkalmazzák ôket. [...] A nagyobb magánbányákban és a Comibolbányáiban egyre több az ajmara bányász, a szakmunkás - ha számszerúen még nincsenek is sokan. A bányász szakma vonzó számukra, mert aki „házon belül van", azaz fix fizetéses, a számos juttatásban is részesül: vásárolhat a ház boltjában, üzemi étkezdében ehet, és halála esetén fiai léphetnek a helyére. A „házon belüli” bányász számára a többi ajmara azt a hatalmas tömeget jelenti, amely bányász akar lenni, és amelyet csak hatékony szakszervezeti harccal lehet a szakmából kiszorítani. [...] Az alkalmi munkások, fốként a kis bányákban dolgozók erôsen ốrzik vidéki közösségükbốl származó identitásukat. A vállalati alkalmazottak (biztosítottak vagy bérleti szerzôdést élvezôk) azonban inkább bányászként, nem pedig eredetük vagy „elốletük” alapján (ajmara, kecsua, földmúvelố vagy indián) tartják számon magukat. 


\section{Az ajmara tanítók}

Bár a statisztikák szerint nem túl magas az ajmara származású tanítók száma, értelmiségi vezetố szerepük miatt mégis fokozott figyelmet érdemelnek. Legfontosabb csoportjuk falusi származású ugyan, de értelmiségiként városban lakik - viszont falvakba jár tanítani. [...] E csoport tagjainak viselkedését két, egymásnak ellentmondó elv vezérli. Egyrészt az oktatási rendszer és az iskolák „haladónak” nevezett ideológiája hajlamos leértékelni a származásukat, és azt az érzést kelteni bennük, hogy jobb tanítók és jobb bolíviaiak lesznek, ha kispanyolosodnak, ami néhány folklóresemény kivételével az ôshonos értékek megtagadását jelenti. Másrészt viszont ajmara eredetük épp ellentétes magatartás felé tolja ôket. Sokan kapcsolatban maradnak szülốfalujukkal, a szünidôben pedig aktívan részt vesznek a különbözó helyi eseményeken, ahol szavuk meghallgatásra talál. [...]

\section{A városban éló ajmarák csoportjai}

Egy mind számarányában, mind gazdasági-társadalmi helyzetébốl fakadóan egyre jelentôsebbé váló csoportról van szó. E csoporton belül is több alcsoportot tudunk megkülönböztetni:

\section{a) Akik elfelejtik származásukat}

A városba költözôre egyrészt nagy nyomás nehezedik annak érdekében, hogy betagozódjék a helyi társadalomba, másrészt pedig rengeteg ajmara-, paraszt- és indiánellenes kijelentéssel, megjegyzéssel találkozik. Érthetố tehát, ha a városba költözôk egy része végül tökéletesen asszimilálódik, „elfelejti” származását és a földijeihez füzô szolidaritás érzését. 
b) Az új városi ajmara szubkultúra

A városba települó ajmara kézmúvesek, kereskedôk, mozgóárusok stb. egy sajátos városi ajmara kultúrát alakítottak ki és tartanak fenn. Az új szubkultúra szolgálatában három, szinte kizárólag városi rádióadó áll, melyek gyakorlatilag egész nap ajmara nyelven sugároznak: hirdetéseket közölnek a tánccsoportok próbájáról, futballmeccsekrôl és gyúlésekrôl, továbbá utcai fúvószenét adnak (általában rezesbandák músorát, néha nádfurulyás és pánsípos muzsikát). Hasonlóan fontos fóruma ennek a szubkultúrának egy spontán ünnepség, a csa'ajjasz. E mögött a szubkultúra mögött nincs semmilyen mozgalom, a megmozdulások résztvevôi nem tüntetni akarnak a jelenlétükkel, hanem egyszerúen csak ott élnek a városban, és otthon akarják érezni magukat benne.

c) Az „itt tartózkodók” szervezett csoportjai

Az itt tartózkodó kifejezést az elmúlt évtizedekben, fóleg az agrárreform után kezdték el használni azokra a falusiakra (zömmel ajmarákra), akik a fóvárosba telepedtek, akkori elképzelés szerint hoszszabb-rövidebb tartózkodásra. Hivatalosan például tarijai, vagy a San Pedro de Buenavista-i itt tartózkodókként (residentes) emlegették óket, ami kifejezte, hogy ezek az emberek egy helyról jöttek. Az itt tartózkodók többsége saját felelôsségére költözik a városba. Vannak, akik bizonyos idô elteltével (vagy a generációváltás során) elveszítik régi lakóhelyi kapcsolataikat, és beilleszkednek az új városi ajmara szubkultúrába, mások viszont fôleg egymás között építenek ki szoros kapcsolatokat. A fôváros régi rezidensei hozták létre az elsô kultúrházakat La Pazban. Ezek a kultúrházak nemcsak társadalmi és szabadidôs tevékenységekkel foglalkoztak, hanem segítettek például a munkakeresésben is. [...] Ezek mentén az informális kötelékek mentén szervezôdnek gazdasági és kulturális vállalkozásaik, egyesületeik, mint a focicsapat, a néptánccsoport és az ünnepeik is. [...] 
Az itt tartózkodók egymás közötti, származás alapú szolidaritása eltekint a vagyoni és származási különbségektôl. Különbözô rezidens csoportok viszonylatában azonban szó sincs ilyesmi rôl; ók mint városi ajmarák, esetleg mint hasonló foglalkozást úzô személyek lehetnek szolidárisak egymással.

d) Az új ajmara értelmiség

A városi ajmara csoportok közül ez a csoport a legkisebb, a jövó szempontjából azonban talán ez a legnagyobb jelentôségú. [...] Az új értelmiség egyrészt indián származású egyetemi oktatókból, egyetemistákból, tanítókból, agronómusokból, önképzô parasztokból verbuválódik, másrészt állami és nemzetközi intézetek kutatóiból, vidékfejlesztôkbôl, akik az ajmara nyelvet és társadalmat tanulmányozták, és akik, ôszinte érdeklődésüknek köszönhetôen rájöhettek kutatásuk értelmére. [...]

\section{Osztályöntudat}

Miután megvizsgáltuk az ajmarák saját magukról kialakított szubjektív képét, összefoglalásként megkísérelem röviden bemutatni, miképp illeszkedik ez az önkép egy társadalmi-gazdasági osztályokban gondolkodó elképzelésbe. 


\section{A társadalmi osztályok \\ és az ajmarák önmagukra használt szubjektív kategóriái}

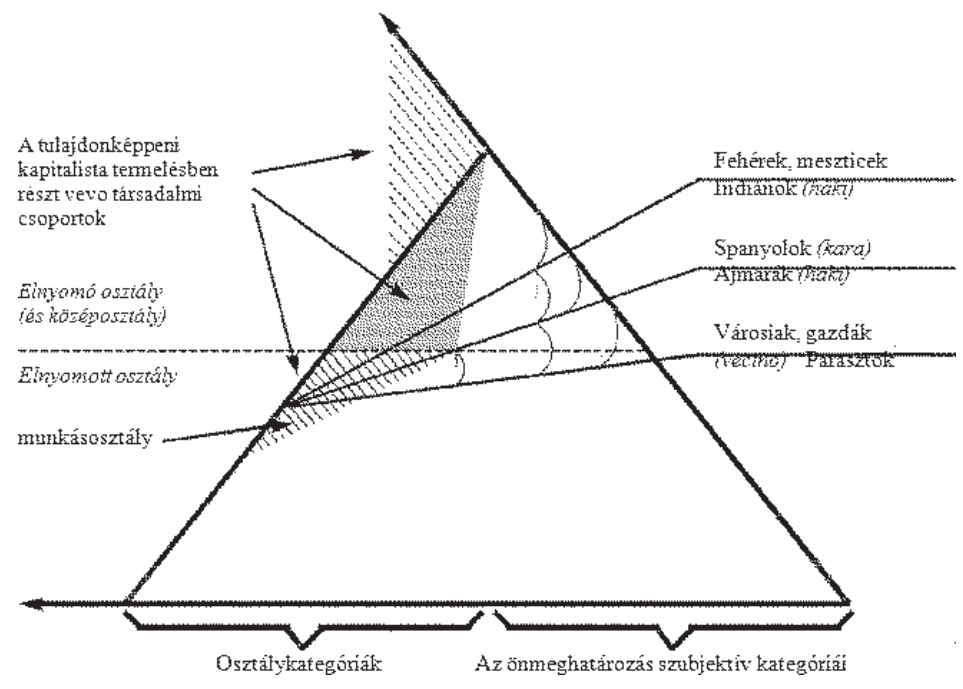

Az ábra a bolíviai társadalomnak azt a részét ábrázolja, amely egyáltalán kapcsolatban áll az ajmara világgal. A jobb oldal az ajmarák által használt kategóriák alapján írja le ezt a világot, a bal oldal pedig a kizsákmányolók és kizsákmányoltak egyszerú alá-fölérendeltségét mutatja. A háromszög (a társadalmi piramis) két szára nem zárt, ami azt jelzi, hogy az ajmara világ nemcsak a bolíviai társadalomba, hanem azon keresztül magasabb szintú rendszerekbe, végsố soron a világgazdaságba illeszkedik.

Ebben a magasabb rendszerben Bolívia maga is az alacsonyabb osztályba, a harmadik világbeli, kizsákmányolt országok közé tartozik, domináns termelési módja szerint pedig kapitalista ország. Ha azonban az ország társadalmi struktúrájából indulunk ki, azt láthatjuk, hogy a lakosságnak csak a kisebbik része termel a kapitalista termelési mód szerint: az ábrán ezt a satírozott terület jelzi; ezen belül is a pontozott terület jelzi a felsô és középosztályok kiterjedt- 
ségét, a vonallal satírozott pedig a tulajdonképpeni munkásosztályét (a bányászokat, a gyári munkásokat és a mezôgazdasági munkásokat). A munkásosztály az elnyomott osztály csúcsán található, jóval azok fölött, akik még csak be sem tudnak lépni a kapitalista termelésbe. Kétségtelen, hogy a munkás áruba bocsátja munkaerejét, és kizsákmányolják, de még mindig sokkal jobban él, és nagyobb megbecsülésnek örvend, mint azok, akik eddig sem jutnak el, mint az önellátó közösségekben élô parasztok. A társadalmi piramis nagyobb része nem vesz részt a piacgazdaságban, hanem prekapitalista termelési mód szerint múködik. Öket a felsôbb osztályok a kis- és nagykereskedôkön, felvásárlókon, külkereskedôkön mint közvetítôkön keresztül érik el és tartják függôségi viszonyban, még ha ez a viszony nem is olyan szoros, mint az agrárreform elốtt volt. [...]

A jobb oldalon, az ajmara identitásoknak megfelelően három vonal mentén szabdaltuk szét a piramist. Mindegyik önelnevezésnek megvan a maga ellentéte, azaz az a csoport, amelyet az önelnevezés kizár. Az indián önelnevezés a legszélesebb kategória, amelybe mindenki beletartozik, aki nem fehér vagy mesztic. Az ajmara ennél szúkebb körre vonatkozik, azokra, akik ajmarául beszélnek. Bár értelemszerúen kizárja például azokat, akik már elutasítják az indiánság bélyegét, oppozíciója mégis kizárólag a spanyol nyelv. A paraszt kategória tulajdonképpen mindenkit kirekeszt, aki városi, ideértve a kisvárosok vecinôit is. Ajmarául az ennek megfelelô szótár lényegesen egyszerúbb: a haki, kontextustól függốen, lehet indián, ajmara vagy paraszt jelentésú, a kara viszont mindenképpen csak a spanyol ajkú fehér-mesztic társadalom tagjára vonatkozhat.

Ha most összehasonlítjuk az ábra két oldalát, láthatjuk, hogy a generatív kategóriák között szoros összefüggés van: az elnyomott osztály java része az indián - ajmara - paraszt önelnevezésekkel illeti magát. De az elnyomott osztályon belül van egy olyan csoport, amelynek tagjai nem tartják magukat sem ajmarának, sem indiánnak, mert ok - munkások.

[...] 
Összefoglalásképpen azt szögezhetem le, hogy az ajmarák szubjektív önmeghatározását érdemes továbbra is kutatni. Idôben gyorsan átalakuló kategóriákról van szó, amelyek viselóikbốl roppant erôs érzelmeket tudnak kiváltani. Az új vallásos mozgalmak és politikai csoportosulások gyakran ki is használják az ajmarák érzelmességét és hiszékenységét, hogy ezeket az indulatokat a saját céljaikra fordítsák, ahelyett, hogy az etnikai kategóriák az etnikai csoport érdekeit szolgálnák.

A szubjektív öndefiníciónak azért van súlya, mert az ajmara identitástudat roppant erôs érzelem. Remélem, hogy hasonlóan ahhoz, ahogy egykor a nacionalizmus hozzásegítette a világ több sarkában az elnyomott népeket szabadságuk kivívásához és a függôségi viszonyok széttöréséhez, az ajmarák felszabadításában is jelentôs szerepet kaphat majd öndefiníciójuk, illetve az „indián”, ,ajmara” vagy „földmúves” fogalmak helyes, negatív társadalmi konnotációktól mentes használata.

\section{Irodalom}

- Albó, Xavier (1975): La paradoja aymara: solidaridad y faccionalismo. In Cuadernos de Investigación, (8). La Paz: CIPCA.

- Achacachi (1976): Rebeldes, pero conservadores. Elhangzott Párizsban, a 42. Amerikanista Kongresszuson [ôshonosok és Gazdálkodók Szimpózium].

- Bolton, Ralph (1973): Agression and Hypoglycemia among the Quolla. In Ethnology, 12: 227-257. Carter, William (1965): Innovation and Marginality: Two South American cases. In America Indígena, 25 (4): 383-392.

- CIPCA (1976): Yungas: los „otros” aymaras. In Cuadernos de Investigación, 11. La Paz: CIPCA. CODEX (1975): Marginalidad y salud. In La situación de los barrios marginales populares en La Paz. La Paz: CODEX.

- Condarco, M. Ramiro (1976): Zárate el tembile Wilka. La Paz.

- Condori, U. Juan (1976): Respuesta de un jóven aymara a Fernando Vaca Toledo. In Semana de Ultima Hora, 4 (6). La Paz. 
- Oughty, Paul (1970): Behind the Back of the City. Provincial Life in Lima, Peru. In Peasants in Cities. William Mangin szerk. Boston: Houghton Mifflin.

- Gutelman, Michel (1975): El modo de producción parcelario. Cuadernos de discusión. Quito: CIESE 1(1) (A 4. fejezet fordítása: „Structures et réformes agraires". Paris: Maspero.)

- Harris, Olivia és Xavier Albó (1975): Monteras y guardatijos: campesinos y mineros en el Norte de Potosí. Cuadernos de Investigación. La Paz: CIPCA.

- Jongking, C. F. (1972): Regional Clubs in Lima, Peru. Amsterdam: CEDLA.

- Leons, William (1972): Dimension of Pluralism in a Changing Bolivian Community. Doktori dolgozat. Pennsylvania State University (fénymásolat).

- Leons, William (1973): Manifesto de Tiwanaku. Kiadás nélküli sokszorosítás.

- Leons, William (1975): Mink'a. La liberación del indio en Bolivia. In Annales de la Ire réunion d'anthropologie des pays de l'aire andine, 92-99. La Paz: Institut Bolivien de la Culture.

- Montagno, Mario (1972): El hombre del suburbio. Oruro: INDICEP.

- Nash, June (1973): Dependency and Exploitation In Worker Consciousness: The Case of Bolívian Tin Mines. Lima.: sokszorosított.

- Nash, June (1976): Alienation, Community, and Class Consciousness. Elhangzott a Bolívia ma címu szimpóziumon. Reinaga, Fausto (1970): La revolución india. La Paz: Burillo.

- Reyes, Celso et al. (1945): Estudio socioeconómica de la provincias Omasuyos, Ingavi y Los Andes. La Paz: Mezogazdasági Minisztérium, kézirat.

- Sandoval, Godofredo et al. (1981): El Centro de Acción Santiago de Ojje (ideiglenes cím). La Paz: CIPCA. Van den Berghe, Pierre (1967) Race and Racism. A Comparative Perspective. New York: Wiley and Sons. Van den Berghe, Pierre (1973): The Use of Ethnic Terms in the Peruvian Social Science Literature. A Conflict, Law and Social Control in the Andes szimpóziumra készült munka. New Orleans: American Anthropological Association.

- Zalles, Jimmy (1976): La iglesia aymara dentro de la iglesia Boliviana, los aymaras dentro de la sociedad Boliviana. Cuadernos de Investigación. CIPCA 12. 